Utah State University

DigitalCommons@USU

1977

\title{
Nutrient transport in surface runoff and interflow from an aspen- birch forest
}

D.R. Timmons

E.S. Verry

R.E. Burwell

R.F. Holt

Follow this and additional works at: https://digitalcommons.usu.edu/aspen_bib

Part of the Forest Sciences Commons

\section{Recommended Citation}

Timmons, D.R.; Verry, E.S.; Burwell, R.E.; Holt, R.F. 1977. Nutrient transport in surface runoff and interflow from an aspen-birch forest. Journal of Environmental Quality. 6(2): 188-192.

This Article is brought to you for free and open access by the Aspen Research at DigitalCommons@USU. It has been accepted for inclusion in Aspen Bibliography by an authorized administrator of DigitalCommons@USU. For more information, please contact

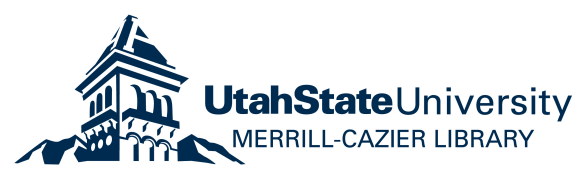


Nutrient Transport in Surface Runoff and Interflow from an Aspen-Birch Forest

\author{
D. R. Timmons, E. S. Verry, R. E. Burwell, and R. F. Holt ${ }^{2}$
}

Copuring tom

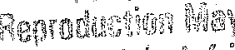

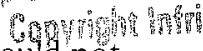

\section{ABSTRACT}

Nutrients transported in surface runoff and interflow from an undisturbed aspen-birch (Populus tremuloides Michx., and Betula papyrifera Marsh.) forest (6.48 ha) in northern Minnesota were measured for 3 years. Surface runoff from snowmelt accounted for $97 \%$ of the average annual surface runoff and for $57 \%$ of the average annual water loss. Slope aspect influenced the amount, rate, and time of snowmelt runoff. In surface runoff, organic nitrogen (N) comprised $80 \%$ of the total $\mathrm{N}$ load, and organic (+ hydrolyzable) phosphorus $(P)$ comprised $45 \%$ of the total $P$ load. The quantities of cations in surface runoff were in the order of calcium $(\mathrm{Ca})$ $>$ potassium $(\mathrm{K})>$ magnesium $(\mathrm{Mg})>\operatorname{sodium}(\mathrm{Na})$. More than $96 \%$ of all the nutrients in surface runoff were transported by snowmelt. The annual volumes of interflow varied only slightly during the 3 years. Compared with surface runoff, the amounts of all the nutrients (except $\mathrm{Na}$ ) and their weighted concentrations decreased in interflow. These nutrient losses from the ecosystem can accumulate in surface waters.

Additional Index Words: nitrogen, phosphorus, potassium, calcium, magnesium, sodium, COD, snowmelt.

The increased accumulation of nutrients in many lakes in the north central United States has caused concern that water quality is deteriorating at an accelerating rate. Nutrient loads from contributing watersheds are influenced by many factors and can change when the watersheds are altered by natural and/or manmade disturbances. Nutrient losses for undisturbed and disturbed forest ecosystems have been reported for other areas, but no data have been reported for the western Great Lakes area.

Nutrient losses in streamflow from an undisturbed northern hardwood forest ecosystem in New Hampshire have been reported (Bormann et al., 1968; Bormann and Likens, 1970). After clear-cutting and repeated herbicide control of regeneration, net losses of $\mathrm{NO}_{3}-\mathrm{N}, \mathrm{K}, \mathrm{Ca}, \mathrm{Al}$, $\mathrm{Mg}$, and $\mathrm{Na}$ were, respectively, $67,21,10,9,7$, and 3 times greater than those in the undisturbed system (Likens et al., 1969; Bormann and Likens, 1970). In Michigan, the effects of clear-cutting on nutrient losses were evaluated in three 60-year-old aspen stands located on good, intermediate, and poor soils (Richardson and Lund, 1975). For the first year, they found little evidence of increased nutrient losses in soil leachate (except $\mathrm{Ca}$ and $\mathrm{Mg}$ ) as a consequence of clear-cutting.

Changes in water chemistry caused by the thinning, clear-cutting, and conversion to pine and grass on southern mixed-hardwood watersheds have been reported by Douglas and Swank (1975). In four contrasting ecosystems they found relatively minor changes in mean annual cation and anion concentrations, and concluded that the

\footnotetext{
${ }^{1}$ Contribution from the North Central Region, Agric. Res. Serv., USDA, Morris, Minn. 56267, and the North Central Forest Exp. Stn., USDA Forest Serv., Grand Rapids, Minn. 55744, in cooperation with the Minnesota Agric. Exp. Stn., Sci. J. Pap. No. 9393. Received 5 Apr. 1976.

${ }^{2}$ Soil Scientist, USDA, Morris, Minn.; Forest Hydrologist, USDA, Grand Rapids, Minn.; Soil Scientist, USDA, Columbia, Mo.; and Soil Scientist, USDA, Morris, Minn., respectively.
}

increased loss of nutrients from the watersheds would not create pollution problems. Recently, Leak and Martin (1975) reported a good relationship between streamwater $\mathrm{NO}_{3}$ during spring and summer and stand age, or age since disturbance for northern hardwoods in the northeast.

In Ohio, Taylor et al. (1971) compared water and nutrient losses from a deciduous hardwood and pine watershed with those from an adjacent farmland watershed. During a 3-year period, they found significantly higher nutrient losses but only slightly greater water loss from farmland. In eastern Ontario, Schindler and Nighswander (1970) used long-term hydrologic data to determine annual nutrient loading for Clear Lake from the 125-ha upland forest watershed. The per hectare losses of inorganic $\mathrm{N}$, total $\mathrm{P}, \mathrm{K}, \mathrm{Na}, \mathrm{Ca}$, and $\mathrm{Mg}$ from this watershed ranged from 23 to $81 \%$ of the respective annual losses reported for the New Hampshire watershed.

Many lakes have watersheds comprised of agricultural or forested land, alone or in combination. Nutrient losses in surface runoff from agricultural plots in Minnesota have been reported (Timmons et al., 1973; Burwell et al., 1975), but more information is needed to evaluate the nutrient contribution from forests to lakes and streamflow. Since northern Minnesota has a large area covered with mixed aspen and white birch, a study was initiated to (i) determine annual nutrient loads transported by surface runoff and interflow from an aspen-white birch forest, and (ii) to evaluate the quantities of nutrients in surface runoff transported by snowmelt and rainfall.

\section{EXPERIMENTAL PROCEDURE}

Runoff plots were installed to collect surface runoff and interflow during 1971 through 1973 from upland forest slopes in Watershed 2 (WS-2), Marcell Experimental Forest, Itasca County, Minnesota (ca. $47^{\circ} 32^{\prime} \mathrm{N} ; 93^{\circ} 28^{\prime} \mathrm{W}$ ). This watershed covers 9.72 ha consisting of a 6.48-ha upland forest with a mature, well-stocked sawlog stand of aspen (Populus tremuloides Michx.) and birch (Betula papyrifera Marsh.), and a 3.24-ha bog with a well-stocked pole stand of black spruce (Picea mariana Mill. B.S.P.). The upland forest has 3.00 ha with northerly aspect and 3.48 ha with southerly aspect ( 30.6 and $35.9 \%$, respectively, of the total watershed area).

One surface and one subsurface plot were installed on each slope aspect. Surface runoff from the upland forest soil (Warba series) flows through the surface organic $(O)$ horizon instead of over the forest floor. The surface runoff plot on the northerly aspect was $1.83 \mathrm{~m}$ wide and $23.16 \mathrm{~m}$ long $(0.004 \mathrm{ha})$ and was located on a $22 \%$ slope; the plot on the southerly aspect was $1.83 \mathrm{~m}$ wide and $18.29 \mathrm{~m}$ long (0.003 ha) and was located on a $26 \%$ slope. Each surface runoff plot extended from the base of the slope near the bog to the top of the slope. With some variation, the equipment used to collect and measure surface runoff was similar to that described by Mutchler (1963). The metal water collection tanks were coated with a chemically inert paint to prevent $\mathrm{P}$ adsorption on the galvanized surface (Latterell et al., 1974). Sampling of snowmelt runoff was facilitated by heating each collection tank shelter 0.5 to $3.3 \mathrm{C}$ when necessary.

Interflow in the upland forest soil moves along the upper boundary of the slowly permeable B2t horizon to the bog water table. To collect this interflow, a 1.82 -m stainless steel wellpoint was placed horizontally at the junction of the A22 and B2t horizons and connected to a collection tank with PVC pipe (Fig. 1). The forest litter and soil horizons to about the $33-\mathrm{cm}$ depth (to the 


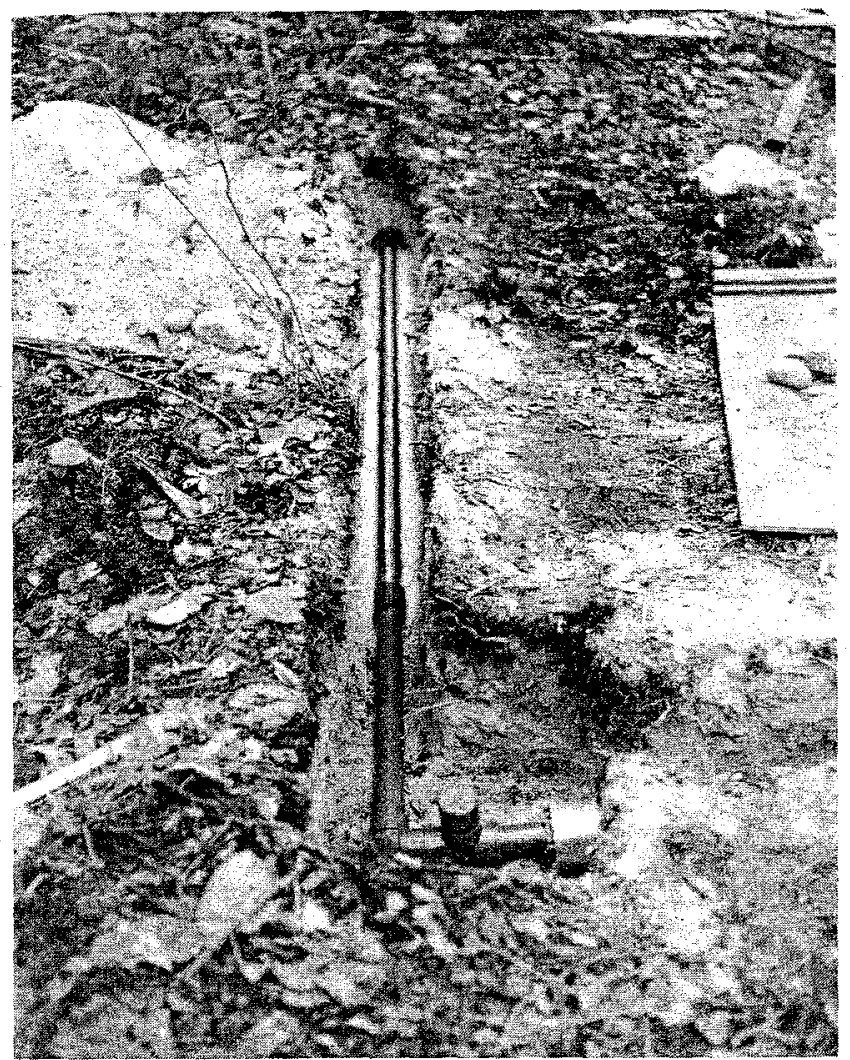

Fig. 1-lnstallation of stainless steel wellpoint at the junction of the $A 22$ and B2t horizons to collect interflow, which comes from the left.

$B 2 t$ horizon) were replaced to their original depths after the wellpoint was installed in a $13-\mathrm{cm}$ wide trench. While refilling the trench a thin stainless steel sheet was placed over the wellpoint at about $5 \mathrm{~cm}$ below the mineral soil surface to help prevent downward movement of surface run off at the interflow collection point. Runoff samples for nutrient analyses were collected after each runoff event. During snowmelt and prolonged rainfall, samples were collected daily or more often. The samples were collected in 1-liter polyethylene containers when runoff was measured, and were refrigerated at 2 to $3 \mathrm{C}$ until analyzed.

Unfiltered portions of each sample were analyzed for Kjeldahl $\mathrm{N}$, total $\mathrm{P}$, and chemical oxygen demand (COD). Filtered portions $(0.45 \mu \mathrm{m})$ were analyzed for $\mathrm{NH}_{4}-\mathrm{N},\left(\mathrm{NO}_{2}+\mathrm{NO}_{3}\right)-\mathrm{N}$, ortho-P, $\mathrm{K}$ $\mathrm{Na}, \mathrm{Ca}$, and $\mathrm{Mg}$. Kjeldahl $\mathrm{N}$ was de termined with a macro-Kjeldahl method (U. S. Environmental Protection Agency, 1974) in which the sample was digested with concentrated $\mathrm{H}_{2} \mathrm{SO}_{4}$ and one KelPak, distilled in to $\mathrm{H}_{3} \mathrm{BO}_{3}$, and titrated with standard $\mathrm{H}_{2} \mathrm{SO}_{4}$. Total $\mathrm{P}$ was measured with a spectrophotometer after digestion with concentrated $\mathrm{HClO}_{4}$ and $\mathrm{HNO}_{3}$, and color development with combined reagent (U.S. Environmental Protection Agency, 1974). Chemical oxygen demand was determined by oxidation with $\mathrm{K}_{2} \mathrm{Cr}_{2} \mathrm{O}_{7}$ in $50 \%$ (vol/vol) $\mathrm{H}_{2} \mathrm{SO}_{4}$ solution at reflux temperature (U. S. Environmental Protection Agency, 1974). During 1971 and 1972, $\mathrm{NH}_{4} \cdot \mathrm{N}$ and $\left(\mathrm{NO}_{2}+\mathrm{NO}_{3}\right)-\mathrm{N}$ were measured with the steam distillation method (Bremner, 1965). During 1973, $\mathrm{NH}_{4}-\mathrm{N}$ and $\left(\mathrm{NO}_{2}+\mathrm{NO}_{3}\right)-\mathrm{N}$ were measured with a Technicon Auto-Analyzer II $^{3}$ (after verifying the different methods agreed) using Technicon's $\mathrm{NH}_{3}$ in water and wastewater, and $\mathrm{NO}_{2}$ and $\mathrm{NO}_{3}$ in-water and wastewater methods, respectively. Ortho-P was measured with a spectrophotometer after color development using combined reagent. Concentrations

\footnotetext{
${ }^{3}$ Trade names are used here solely to provide specific information. Mention of a trade name does not constitute a guarantee or warranty and does not signify that the product is approved to the exclusion of other comparable products.
}

of $\mathrm{K}, \mathrm{Na}, \mathrm{Ca}$, and $\mathrm{Mg}$ were determined by atomic absorption spectroscopy (Issac and Kerber, 1971). Organic N was determined by subtracting $\mathrm{NH}_{4}-\mathrm{N}$ from $\mathrm{Kjeldahl} \mathrm{N}$, and organic $\mathrm{P}$ (including hydrolyzable) was determined by subtracting ortho-P from total $P$.

Nutrient losses in surface runoff from each slope aspect were determined for each sampling interval or runoff event as the product of water loss quantities and their respective nutrient concentrations. Seasonal nutrient losses were determined as the accumulated sum of nutrients in snowmelt runoff or rainfall runoff. The respective water and nutrient losses from the northerly and southerly aspects were combined to obtain total losses from the upland aspen area, and then divided by 6.48 to determine per hectare values.

Interflow from the upland forest was estimated by a total water shed hydrograph separation technique. An analysis of total watershed hydrographs showed that logs of the recession leg slope were significantly higher $(\alpha=0.001)$ during July and August than at other times. July and August recession legs represent flow periods from the bog only because the runoff plots did not collect flow during this period. July and August hydrographs for 10 years (1961-1970) for WS-2 were used to calculate an average recession leg for the flow originating in the bog from precipitation and included both high and low flow data. An annual bog-water-only hydrograph was then constructed using the average bog recession leg and measured rising legs from the total hydrograph. Interflow from the upland was estimated as the difference between the total watershed hydrograph and the bog-water-only hydrograph. We interpret the difference in hydrographs as interflow because upland surface flow always occurred before watershed flow, and the bogwater-only hydrograph was not subtracted from the total watershed hydrograph until after the initial snowmelt rise in early April (streamflow always ceased during winter). Nutrient losses in interflow were determined as the product of the average concentration for two consecutive samplings and the quantity of interflow between the two samplings. When interflow samples were obtained from both northerly and southerly aspects simultaneously, the nutrient concentrations were averaged to determine interflow nutrient losses; otherwise, the concentrations from each aspect were used separately. Weighted concentrations were calculated by converting the $\mathrm{kg}$ of nutrients/ha per $\mathrm{cm}$ of water loss to ppm.

\section{RESULTS AND DISCUSSION}

Annual surface runoff from WS-2 upland during the 3 years ranged from 5.10 to $12.52 \mathrm{~cm}$, and interflow ranged from 5.66 to $5.82 \mathrm{~cm}$ (Table 1). Snowmelt accounted for 93 to $100 \%$ of the total annual surface runoff, and for 46 to $68 \%$ of the total annual water loss from the aspen-birch forest. After snowmelt surface runoff ceased, measurable $(>0.013 \mathrm{~cm})$ surface runoff events caused by rainfall contributed negligible amounts of water to the total annual water loss. These measurable runoff events occurred only after heavy rainfalls and/or during several consecutive days of rainfall.

Since 1961, when hydrologic and climatic measurements for WS-2 started, annual precipitation has ranged from 59.39 to $88.49 \mathrm{~cm}$, and averaged $77.09 \mathrm{~cm}$. During the 3 years of nutrient sampling, annual precipitation averaged $79.03 \mathrm{~cm}$. In early March each year, just before the spring thaw, average depth and water content of the snowpack were uniform for both slope aspects of the aspen-birch forest; the amount of snowmelt surface runoff was related to the snowpack water content (Table 1). Slope aspect influenced the amount of snowmelt surface runoff (Table 1) as well as the time and rate. Snowmelt from the southerly aspect began earlier, ran off at a faster rate, and contributed more water to surface runoff than the snowpack on the northerly aspect. Although the ef. fect of slope aspect on interflow wasn't delineated by the 
Table 1-Surface and interflow water losses from the aspen-birch forest and precipitation received during 1971-1973

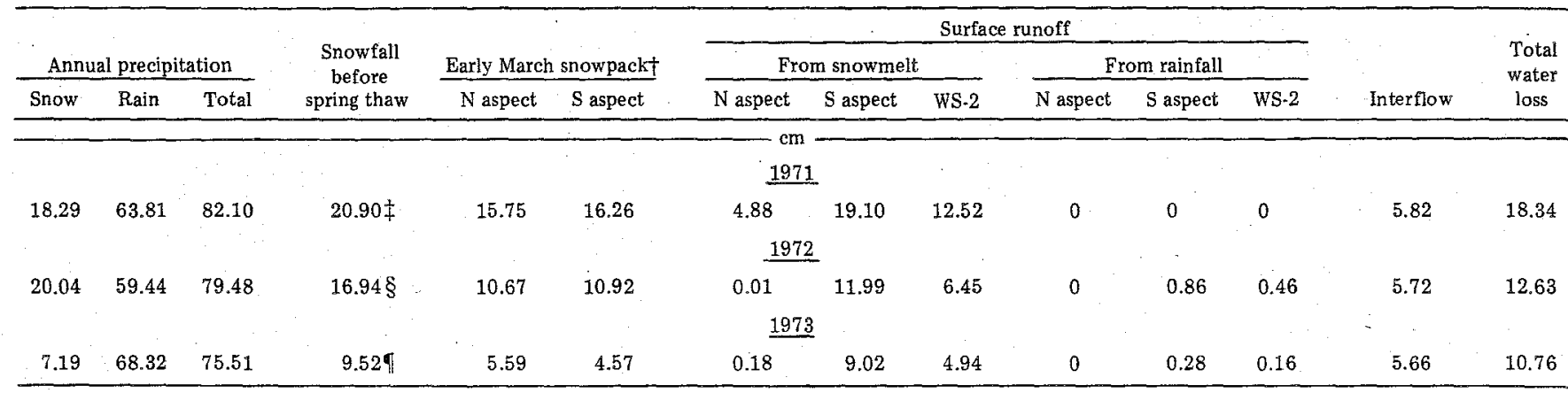

† Average $\mathrm{H}_{2} \mathrm{O}$ content for 10 sampling sites during the first week in March.

Snow fall as water from 10 Nov. 1970 to 4 Apr. 1971 .

method used to determine interflow volumes, more interflow was consistently collected from the northerly aspect than the southerly aspect during snowmelt.

Nutrient losses in surface runoff from the aspen-birch forest are given in Table 2. Annual total $\mathrm{N}$ losses ranged from 1.13 to $2.12 \mathrm{~kg} /$ ha with 74 to $87 \%$ as organic $\mathrm{N}$. More $\mathrm{NH}_{4}-\mathrm{N}$ than $\left(\mathrm{NO}_{2}+\mathrm{NO}_{3}\right)-\mathrm{N}$ (hereafter shown as $\mathrm{NO}_{3}-\mathrm{N}$ ) was transported in surface runoff but only for 2 of the 3 years. The amounts of inorganic $\mathrm{N}\left(\mathrm{NH}_{4}-\mathrm{N}+\right.$ $\mathrm{NO}_{3}-\mathrm{N}$ ) were low compared to the organic $\mathrm{N}$ and ranged from 0.19 to $0.55 \mathrm{~kg} / \mathrm{ha}$ during the 3 years. Total $P$ losses ranged from 0.13 to $0.30 \mathrm{~kg} / \mathrm{ha}$ (Table 2), with more soluble inorganic $\mathrm{P}$ (ortho-P) than organic $\mathrm{P}$ transported in surface runoff during 2 of the 3 years. However, based on the overall average, the ortho- $\mathrm{P}$ and organic $\mathrm{P}$ were almost equal. Average annual $\mathrm{Ca}$ losses were about 3 and 20
$\S$ Snowfall as water from 19 Nov. 1971 to $13 \mathrm{Apr} .1972$

I Snowfall as water from 7 Nov. 1972 to 28 Mar. 1973.

times greater than the respective total $N$ and $P$ losses, and annual $\mathrm{K}$ losses were about 2 and 13 times greater, respectively. Generally, losses of cations in surface runoff were in the order of $\mathrm{Ca}>\mathrm{K}>\mathrm{Mg}>\mathrm{Na}$, which reflected the concentrations of these cations in yellowing aspen leaves just beginning to fall from the tree (Verry and Timmons, 1976). During the next spring thaw, these leaves would be subject to leaching by snowmelt runoff.

Nutrients in interflow are also presented in Table 2. Since the method used to determine interflow precludes separating precisely the interflow nutrients transported by snow and rain, the losses are given on an annual basis. As in surface runoff, organic $\mathrm{N}$ comprised the greatest portion of the annual total $\mathrm{N}$ loss in interflow (88 to $91 \%$ ), but averaged $0.67 \mathrm{~kg} /$ ha per year $<$ did organic $\mathrm{N}$ in surface runoff. For 2 of the 3 years, $\mathrm{NH}_{4}-\mathrm{N}$ losses were

Table 2-Average nutrient losses measured in surface runoff, interflow, and total water loss from the aspen-birch forest

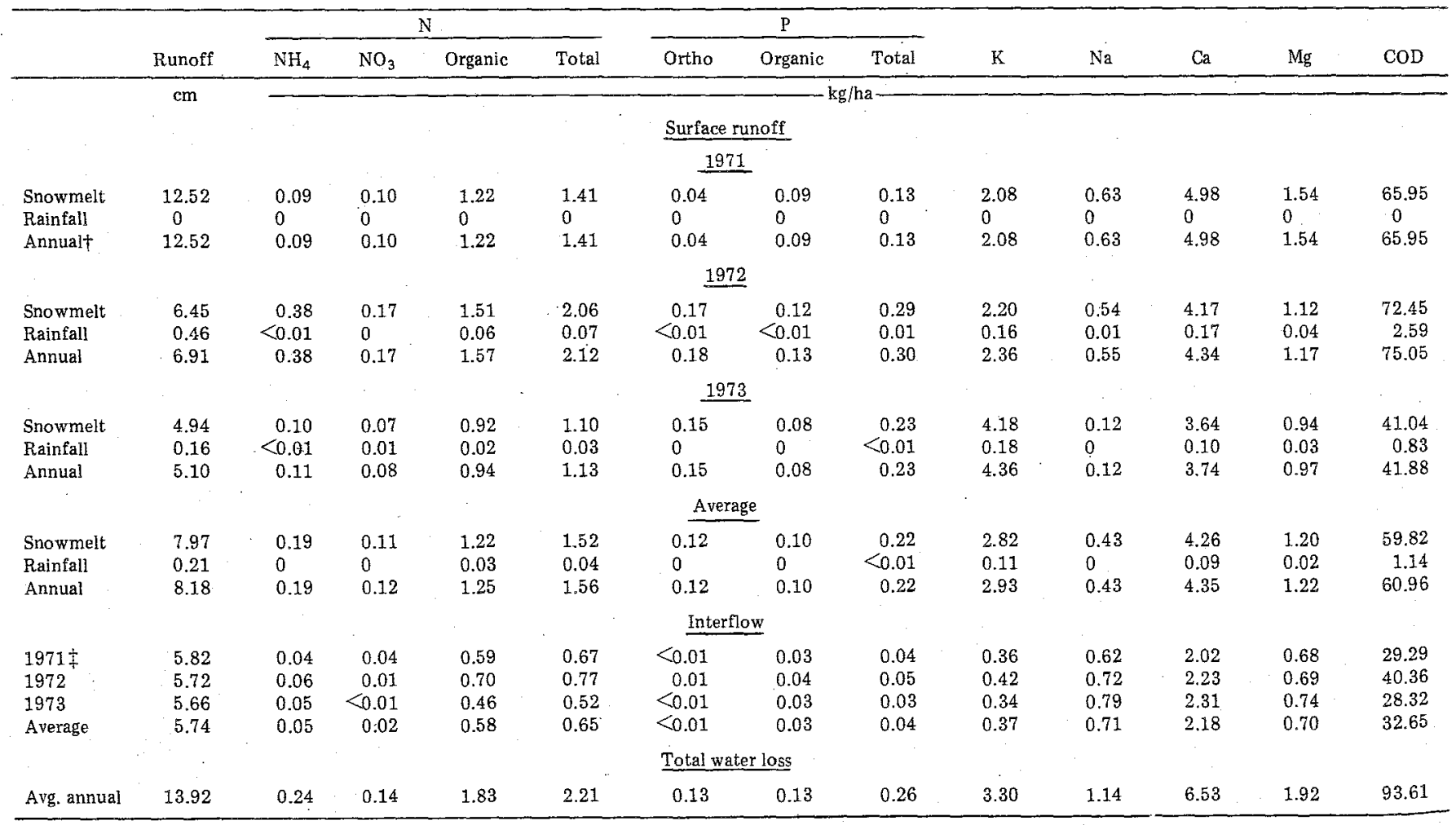

† Annual losses may not be the exact sum of snowmelt losses and rainfall losses due to rounding off.

Computation of interflow volumes did not allow separation of snowmelt and rainfall components. 
greater than $\mathrm{NO}_{3} \mathrm{~N}$ losses. The amounts of inorganic $\mathrm{N}\left(\mathrm{NH}_{4}-\mathrm{N}+\mathrm{NO}_{3}-\mathrm{N}\right)$ in interflow were 42,13 , and $26 \%$ of the amounts in surface runoff for 1971, 1972, and 1973, respectively.

Average annual total P loss in interflow was only $18 \%$ of the annual total $P$ loss in surface runoff (Table 2). The decrease of ortho- and organic $\mathbf{P}$ loads in interflow as compared with surface runoff, and the change of the ortho/ organic $\mathrm{P}$ ratio, indicated that $\mathrm{P}$ (especially ortho-P) leached from the most recent forest litter was utilized and/or immobilized in the partially decomposed organic horizons and/or mineral soil. Except for $\mathrm{Na}$, the cations in interflow also decreased. Average annual $\mathrm{K}, \mathrm{Ca}$, and $\mathrm{Mg}$ losses in interflow were 13,50 , and $57 \%$ of their respective annual losses in surface water. Although the average annual interflow was about $70 \%$ of the average annual surface runoff, the annual $\mathrm{Na}$ loss in interflow was nearly twice that for surface runoff.

The average annual loss of that portion of the organic matter oxidized by a strong oxidant (COD) in surface runoff was about twice the loss in interflow. During the 3 years, the average COD concentration was $78 \mathrm{mg} /$ liter with an overall range of 23 to $250 \mathrm{mg} / \mathrm{liter}$. In west central Minnesota, the COD concentration of Eagle Lake outlet averaged $26 \mathrm{mg} / \mathrm{liter}$ and the drainage water from its 3,645-ha agricultural watershed ranged from 2 to 47 $\mathrm{mg} /$ liter with an average of $22 \mathrm{mg} /$ liter (unpublished data). Both surface runoff and interflow from the aspen-birch forest contained greater COD concentrations than did water from an agricultural watershed.

Except for $\mathrm{Na}, 64$ to $92 \%$ of the total annual nutrient losses from the aspen-birch forest occurred in surface run- off, while only $59 \%$ of the total water loss was surface runoff. When surface runoff from snowmelt passes through the organic horizon, there appears to be a net leaching effect for all nutrients except $\mathrm{NH}_{4}-\mathrm{N}$ and $\mathrm{NO}_{3}-\mathrm{N}$ since nutrient loads in the snowpack are low. ${ }^{4}$ With $97 \%$ of the annual surface runoff from snowmelt, most surface runoff occurs at temperatures very near freezing and apparently passes through the forest floor with little opportunity for immobilization and/or utilization.

Nutrient inputs from precipitation and aspen throughfall are important sources contributing nutrients to the forest floor. Except for $\mathrm{NH}_{4}-\mathrm{N}$ and $\mathrm{NO}_{3}-\mathrm{N}$, the quantities of nutrients contributed annually by precipitation were increased by aspen throughfall. ${ }^{4}$ However, the annual nutrient losses in surface runoff plus interflow showed reductions of about 2 to 12 times the amount contributed by aspen throughfall (except for $\mathrm{Na}$ ), so the forest floor and mineral soil plus all the biological processes appear to be acting annually as nutrient sinks.

Average annual inorganic $N$ loss from the aspen-birch forest was 21,30 , and $37 \%$, respectively, compared to the losses reported for New Hampshire (Bormann et al., 1968), eastern Ontario (Schindler and Nighswander, 1970), and Ohio (Taylor et al., 1971). However, total P loss from the aspen-birch forest was about 3 times greater than total $P$ loss from the climax hardwoods in eastern Ontario and about 5 times greater than the deciduous hardwood and pine in Ohio.

\footnotetext{
${ }^{4}$ Personal communication from E. S. Verry, North Central Forest Experiment Station, U. S. Forest Service, Grand Rapids, Minn.
}

Table 3-Weighted nutrient concentrations for surface runoff, interflow, and total water loss from the aspen-birch forest

\begin{tabular}{|c|c|c|c|c|c|c|c|c|c|c|c|c|}
\hline & \multicolumn{4}{|c|}{$N$} & \multicolumn{3}{|c|}{$\mathrm{P}$} & \multirow[b]{2}{*}{$\mathrm{K}$} & \multirow[b]{2}{*}{$\mathrm{Na}$} & \multirow[b]{2}{*}{$\mathrm{Ca}$} & \multirow[b]{2}{*}{$\mathrm{Mg}$} & \multirow[b]{2}{*}{$\mathrm{COD}$} \\
\hline & $\mathrm{NH}_{4}$ & $\mathrm{NO}_{3}$ & Organic & Total & Ortho & Organic & Total & & & & & \\
\hline \multicolumn{13}{|c|}{ Surface runoff } \\
\hline \multicolumn{13}{|c|}{1971} \\
\hline Snowmelt & 0.07 & 0.08 & 0.97 & 1.12 & 0.03 & 0.07 & 0.10 & 1.66 & 0.50 & 3.97 & 1.23 & 52.7 \\
\hline Rainfall & -. & $\cdots$ & $\cdots$ & -- & - & - &.- & .. & $-\infty$ & -. &.- & .. \\
\hline Annual & 0.07 & 0.08 & 0.97 & 1.12 & 0.03 & 0.07 & 0.10 & 1.66 & 0.50 & 3.97 & 1.23 & 52.7 . \\
\hline \multicolumn{13}{|c|}{1972} \\
\hline Snowmelt & 0.58 & 0.27 & 2.33 & 3.18 & 0.26 & 0.19 & 0.45 & 3.42 & 0.83 & 6.46 & 1.74 & 112.2 \\
\hline Rainfall & 0.16 & 0.10 & 1.40 & 1.67 & 0.14 & 0.14 & 0.28 & 3.42 & 0.20 & 3.66 & 0.94 & 55.7 \\
\hline Annual & 0.55 & 0.26 & 2.27 & 3.08 & 0.25 & 0.19 & 0.44 & 3.42 & 0.79 & 6.28 & 1.68 & 108.5 \\
\hline \multicolumn{13}{|c|}{$\underline{1973}$} \\
\hline Snowmelt & 0.20 & 0.15 & 1.87 & 2.22 & 0.30 & 0.15 & 0.45 & 8.46 & 0.23 & 7.36 & 1.91 & 83.0 \\
\hline Rainfall & 0.41 & 0.33 & 1.26 & 2.00 & 0.22 & 0.14 & 0.36 & 11.49 & 0.22 & 6.53 & 1.71 & 52.5 \\
\hline Annual & 0.20 & 0.15 & 1.85 & 2.21 & 0.30 & 0.15 & 0.45 & 8.56 & 0.23 & 7.34 & 1.90 & 82.1 \\
\hline \multicolumn{13}{|c|}{ Average } \\
\hline Snowmelt & 0.29 & 0.16 & 1.72 & 2.18 & 0.20 & 0.14 & 0.33 & 4.51 & 0.52 & 5.93 & 1.63 & 82.6 \\
\hline Rainfal] & 0.28 & 0.22 & 1.33 & 1.83 & 0.18 & 0.14 & 0.32 & 7.46 & 0.21 & 5.10 & 1.32 & 54.1 \\
\hline Annual & 0.28 & 0.16 & 1.70 & 2.14 & 0.19 & 0.14 & 0.33 & 4.54 & 0.51 & 5.86 & 1.61 & 81.1 \\
\hline \multicolumn{13}{|c|}{ Interflow } \\
\hline $1971 \dagger$ & 0.07 & 0.07 & 1.01 & 1.16 & 0.01 & 0.06 & 0.07 & 0.62 & 1.07 & 3.46 & 1.16 & 50.3 \\
\hline 1972 & 0.11 & 0.02 & 1.23 & 1.35 & 0.02 & 0.07 & 0.09 & 0.73 & 1.26 & 3.89 & 1.21 & 70.5 \\
\hline 1973 & 0.10 & 0.01 & 0.81 & 0.92 & 0.01 & 0.05 & 0.06 & 0.60 & 1.40 & 4.07 & 1.31 & 50.0 \\
\hline Average & 0.09 & 0.04 & 1.02 & 1.14 & 0.01 & 0.06 & 0.07 & 0.65 & 1.24 & 3.81 & 1.22 & 56.9 \\
\hline \multicolumn{13}{|c|}{ Total water loss } \\
\hline Average annual & 0.19 & 0.10 & 1.36 & 1.65 & 0.11 & 0.10 & 0.20 & 2.63 & 0.85 & 4.88 & 1.42 & 69.5 \\
\hline
\end{tabular}

$\dagger$ Computation of interflow volumes did not allow separation of snowmelt and rainfall components. 
Losses of $\mathrm{Na}, \mathrm{Ca}$, and $\mathrm{Mg}$ (average annual) from the aspen-birch forest and eastern Ontario hardwoods were about equal but were less than respective losses from the New Hampshire sugar maple-beech-yellow birch forest (Bormann and Likens, 1970). Except for the Ohio watershed, average annual $\mathrm{K}$ loss from the aspen-birch forest was greatest. Average annual nutrient losses in interflow from the aspen-birch forest were only 3 to $38 \%$ of the nutrient losses measured in soil leachate under aspen in Michigan (Richardson and Lund, 1975). For two soils with aspen-birch cover from northern Minnesota, estimated annual percolation losses of $\mathrm{P}, \mathrm{K}$, and $\mathrm{Ca}$ from soil columns (Severson et al., 1975) were about the same as respective losses in interflow from WS-2.

Weighted concentrations provide a basis to compare nutrients in surface runoff and interflow and to assess the interyear variation for each. Except for $\mathrm{Na}$, the average annual weighted concentrations for all the other nutrients were highest in surface runoff (Table 3 ). For both surface runoff and interflow, the $\mathrm{NH}_{4}-\mathrm{N}$ to $\mathrm{NO}_{3} \mathrm{~N}$ ratios were about $2: 1$. The ratio of inorganic $\mathrm{N}$ to organic $\mathrm{N}$ increased from about $1: 4$ in surface runoff to $1: 8$ in interflow, so the inorganic $\mathrm{N}$ forms in interflow were utilized and/or immobilized before they were collected at the slope bottom. The average weighted ortho-P concentration decreased nearly 20 -fold from surface runoff to interflow, whereas the organic $\mathrm{P}$ decreased about 2 -fold. Weighted concentrations of $\mathrm{K}, \mathrm{Ca}, \mathrm{Mg}$, and $\mathrm{COD}$ in interflow were $14,65,76$, and $70 \%$ of their respective values in surface runoff. The data indicate that interyear variations for average annual weighted concentrations were less in interflow than in surface runoff.

These data present nutrient losses from an undisturbed aspen-birch ecosystem and will provide a base for comparing water quality changes when disturbances occur. $\mathrm{Nu}$ trient loads from similar upland areas to surface waters can also be estimated by using average weighted concentrations (Table 3) and water losses. Site variation must be considered in estimating nutrient losses. For three soils under aspen in northern Minnesota, Alban (1974), in a soil sampling study, reported that the average coefficients of variation for $\mathrm{N}, \mathrm{P}, \mathrm{K}, \mathrm{Ca}$, and $\mathrm{Mg}$ ranged from 14 to 17,13 to 31 , and 21 to 24 for the forest floor, surface soil $(0-25 \mathrm{~cm})$, and subsoil $(25-102 \mathrm{~cm})$, respectively. Annual nutrient losses estimated from the total average annual weighted concentrations (surface runoff and interflow combined) should give reasonable loss values providing the percent interflow is about the same and the annual water loss is known. Finally, the separation of surface runoff and interflow enable a finer breakdown of output components considered in the interpretation of nutrient cycling studies.

\section{LITERATURE CITED}

1. Alban, D. H. 1974. Soil variation and sampling intensity under red pine and aspen in Minnesota. North Central For. Exp. Stn., St. Paul, Minn. USDA For. Serv, Res. Pap. NC-106. $10 \mathrm{p}$.

2. Bormann, F. H., and G. E. Likens. 1970. The nutrient cycles of an ecosystem. Sci. Am. 223(4):92-101.

3. Bormann, F. H., G. E. Likens, D. W. Fisher, and R. S. Pierce. 1968. Nutrient loss accelerated by clear-cutting of a forest ecosystem. Science 159:882-884.

4. Bremner, J. M. 1965. Inorganic forms of nitrogen. In C. A. Black (ed.) Methods of soil analysis. Part 2. Agronomy 9: 11 79-1237. Am. Soc, of Agron., Madison, Wis.

5. Burwell, R. E., D. R. Timmons, and R. F. Holt. 1975. Nutrient transport in surface runoff as influenced by soil cover and seasonal periods. Soil Sci. Soc. Am. Proc. 39:523-528.

6. Douglas, J. E., and W. T. Swank. 1975. Effects of management practices on water quality: Coweeta Hydrologic Laboratory, North Carolina. USDA For. Serv. Gen. Tech. Rep. NE-13.

7. Issac, R. A., and J. D. Kerber. 1971. Atomic absorption and flame photometry: Techniques and uses in soil, plant, and water analysis. p. 17-37. In L. M. Walsh (ed.) Instrumental methods for analysis of soils and plant tissue. Soil Sci. Soc. Am., Madison, Wis.

8. Latterell, J.J., D. R. Timmons, R. F. Holt, and E. M. Sherstad. 1974. Sorption of orthophosphate on the surface of water sample containers. Water Resour. Res. 10:865-869.

9. Leak, W. B., and C. W. Martin. 1975. Relationship of stand age to streamwater nitrate in New Hampshire. USDA For. Serv. Res. Note NE-2 11.

10. Likens, G. E., F. H. Bormann, and N. M. Johnson. 1969. Nitrification: Importance to nutrient losses from a cutover forested ecosystem. Science 163:1205-1206.

11. Mutchler, C. K. 1963. Runoff plot design and installation for soil erosion studies. USDA-ARS 41-79.

12. Richardson, C. J., and J. A. Lund. 1975. Effects of clearcutting on nutrient losses in aspen forests on three soil types in Michigan. p. 673-686. In F. G. Howell, J. B. Gentry, and M. H. Smith (ed.) Mineral cycling in Southeastern ecosystems. ERDA Symposium Series (CONF-740513). Technical Information Center, Office of Public Affairs. U. S. Energy Res. and Dev. Admin., Washington, D. C.

13. Schindler, D. W., and J. E. Nighswander. 1970. Nutrient supply and primary production in Clear Lake, Eastern Ontario. J. Fish. Res. Board Can. 27:2009-2036.

14. Severson, R. C., D. F. Grigal, and H. F. Ameman. 1975. Percolation losses of phosphorus, calcium, and potassium from some Minnesota forest soils. Soil Sci. Soc. Am. Proc. 39: 540-543.

15. Taylor, A. W., W. M. Edwards, and E. C. Simpson. 1971. Nutrients in streams draining woodland and farmland near Coshocton, Ohio. Water Resour. Res. 7:81-89.

16. Timmons, D. R., R. E. Burwell, and R. F. Holt. 1973. Nitrogen and phosphorus losses in surface runoff from agricultura! land as influenced by placement of broadcast fertilizer. Water Resour. Res, 6:1367-1375.

17. U. S. Environmental Protection Agency. 1974. Manual of methods for chemical analysis of water and wastes. Office of Technol. Transfer, Washington, D. C.

18. Verry, E. S., and D. R. Timmons. 1976. Elements in leaves of a trembling aspen clone by crown position and season. Can. J. For. Res. 6(3):436-444. 